\title{
Web-Based Patient Registration System Design Based on National Standards of Hospital Accreditation at Balung Hospital Jember in Indonesia
}

\author{
Gamasiano Alfiansyah* \\ Department of Health \\ Politeknik Negeri Jember \\ Jember, Indonesia \\ gamasiano.alfiansyah@polije.ac.id
}

\author{
Mudafiq Riyan Pratama \\ Department of Health \\ Politeknik Negeri Jember \\ Jember, Indonesia \\ mudafiq.riyan@polije.ac.id
}

\author{
Selvia Juwita Swari \\ Department of Health \\ Politeknik Negeri Jember \\ Jember, Indonesia \\ selvia@polije.ac.id
}

\begin{abstract}
Balung Hospital as a referral health facility provides inpatient, outpatient, and emergency services. Patient registration at Balung Hospital is still carried out manually. Before receiving outpatient services, patients must register by queuing at the registration point. In addition, information regarding doctor's practice days and hours can only be obtained when the patient comes to the hospital which is inefficient and taking sometimes. The purpose of this study was to design a patient registration information system based on web. The research method used was the waterfall approach. The waterfall method consists of planning, system design, programming, testing, implementation and maintenance steps. In this article, the results made up to the system design stage are in the form of system flow design, database design, and web-based interface design. The interface design is built with HTML5, CSS3, JavaScript, and the Bootstrap framework technology. This interface design was implemented in the CodeIgniter 4 framework to make it easier to build the back-end system. The interface design is responsive, so it can be accessed properly on a smartphone screen. So that patients can register easily, either via desktop or smartphone.
\end{abstract}

Keywords—design, system, registration, hospital

\section{INTRODUCTION}

Hospital is a health service institution that provides complete individual health services that provide inpatient, outpatient and emergency services [1][2]. The high number of outpatients is an indicator of the hospital's success in managing the trust of the people who carry out medical examinations at the hospital [3]. Balung Hospital as a referral health facility provides specialist outpatient services.

Patients Registration at Balung Hospital is still carried out manually. Before receiving outpatient services, patients must register by queuing at the registration unit. It will take a long time and be ineffective [4]. In addition, information regarding doctor's service hours can only be obtained when the patient comes to the hospital. Balung Hospital must pay attention to the length of time required by patients considering the minimum service standard for outpatient waiting time is less than 60 minutes, from the patient registering until being served by a specialist.
Recently, the lagging level of information management cannot meet hospital management's needs and become an obstacle to hospital development [5]. For this reason, it is necessary to improve the management of outpatient registration to improve the waiting time for outpatients and increase access to information needed by the community [68].

The online patient registration system is an effort that can be implemented to solve problems in the outpatient services of Balung Hospital. This system is one of the elements of hospital accreditation assessment, as contained in the second chapter of the standard Access to Hospitals and Service Continuity [9]. Balung Hospital will carry out hospital accreditation in 2020. So that with this system, Balung Hospital will get more value in achieving national hospital accreditation standards, and Balung Hospital can improve the quality of patient services [10].

The purpose of this study was to design an outpatient registration information system based on web based on the national hospital accreditation standards at Balung Hospital. The research method used is the Systems Development Life Cycle or the waterfall approach. The waterfall method has the following steps: planning, system design, programming, testing, implementation and maintenance [11].

\section{RESEARCH METHOD}

This research used the waterfall method. This research consists of several stages, such as analysis, design, implementation, testing, implementation and maintenance. But in this article, this research examined the stages of analysis and design of the patient registration system at Balung Hospital

\section{A. Analysis}

At this stage, an analysis of the problems was carried out. It has been conducted problem analysis, analysis of data requirements, analysis of software requirements, and analysis of hardware requirements. 


\section{B. Design}

At this stage, a system design was carried out in order to provide an overview of the system flow, database design, the relationship of objects involved in the system. The design at this stage were a flowchart and entity relationship diagram.

\section{RESULTS}

\section{A. Analysis}

The first analysis was problem analysis. At this stage, an analysis of the problems that occurred at Balung Hospital was carried out. The problem analysis was the first stage in system design. At this stage, an analysis of the problems that occurred at Balung Hospital was carried out. The problem was patients must come to the hospital and queue to register at the intended clinic. After getting a queue number, patients queued again to meet the doctor at the destination clinic. It could be concluded that the weakness of old system was the queuing process that occurs twice. Based on these problems, it was necessary to provide a web based online registration system that could reduce queues at Balung Hospital.

Data need included clinical data, doctors, service schedules, and requirements for patient registration. The software needed includes the technology and framework used to build the system, that was the Bootstrap framework to build a front-end system which included HTML5, CSS3, and JavaScript. Meanwhile, the database used was MySQL that available in the XAMPP application.

\section{B. Design}

The system design was carried out in order to provide an overview of the flow of the system and database design. The stage of the system design included a flowchart and entity relationship diagram.

The flowchart system is depicted in Figure 1. The flowchart explains the relationship between the patient and the staff who is connected through the system. Patients can choose the type of enrollment whether on their own request, outpatient, or emergency department. There are also two types of patients, consists of general patients and SPM/BPJS/another insurance. SPM is patients registered by the government as poor patients. Each type of patient, the registration fee is different. Registration fees must be transferred to a bank account belonging to the Balung Hospital, then verified by hospital officials. After that, the patient gets a queue number and patients comes to the hospital according to the time set by the system.

Furthermore, the database design, tables, and relationships for each table were created. The following table structure and its relationships are depicted in Figure 2.

At the registration stage, if the patient has previously registered then the patient only enters the patient number or no_rm (medical record number) from the "patient" table. Patients can register at any time that recorded in the "pendaftaran_patient" table (patient registration table) adjusted for no_rm. Patients who register can choose 3 types of registration whether it is APS (On Own Request), RJ (Outpatient), or IGD (Emergency Room), and choose the intended clinic. Each patient registers, the patient is required to make a transfer and upload proof of transfer according to the registration fee set by Balung Hospital.
After the flowchart and database were designed, we built the front-end system (user interface). It was started by building the profile interface of the Balung Hospital which can be seen in Figure 3.

It is through this page that a menu for patient registration was provided. Figures 4, 5, and 6 are patient registration forms which have 3 stages, that are filling out biodata, choosing clinical services, and reviewing the completed forms.

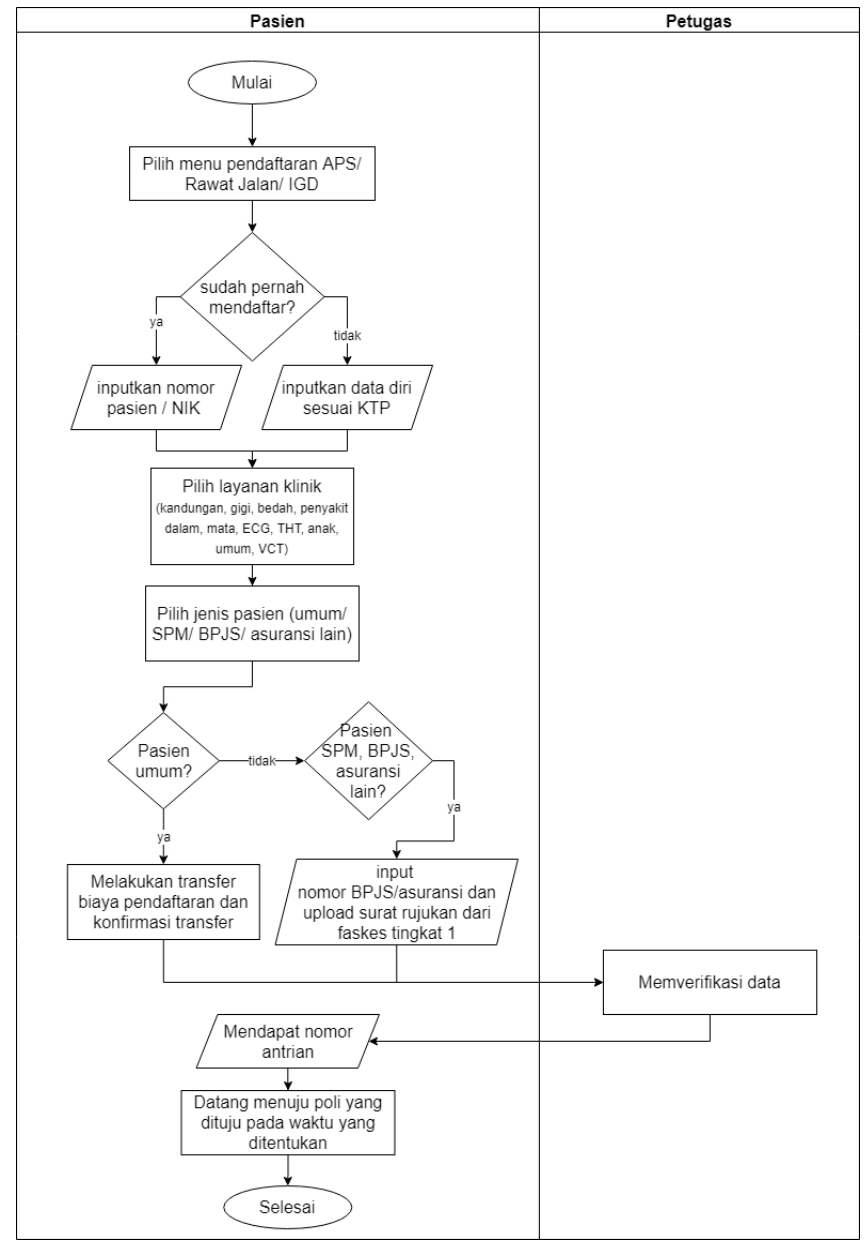

Fig. 1. Flowchart System

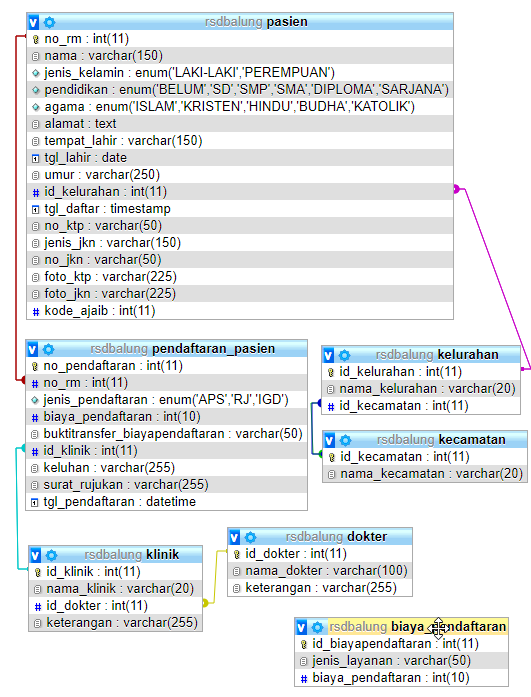

Fig. 2. Entity Relationship Diagram 

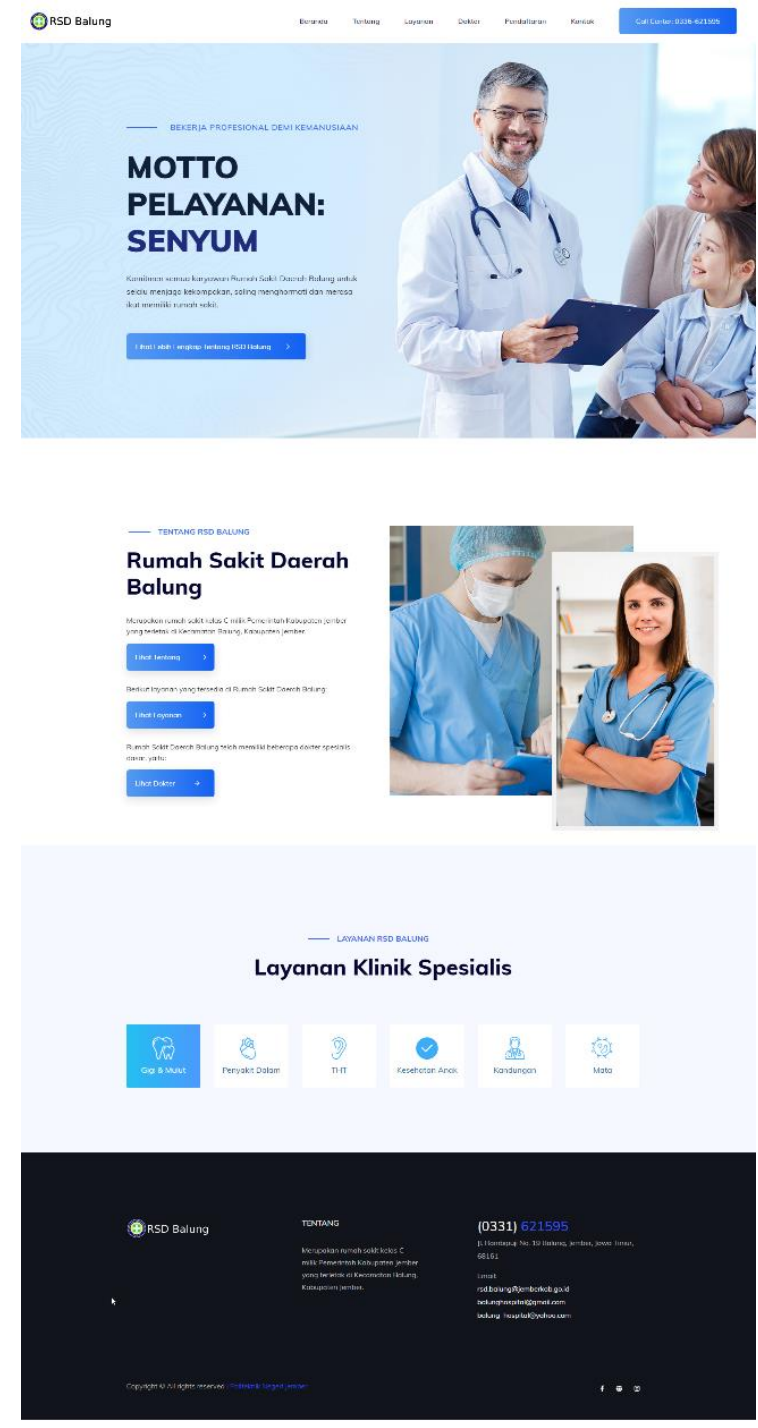

Fig. 3. Page of web profile Balung Hospital

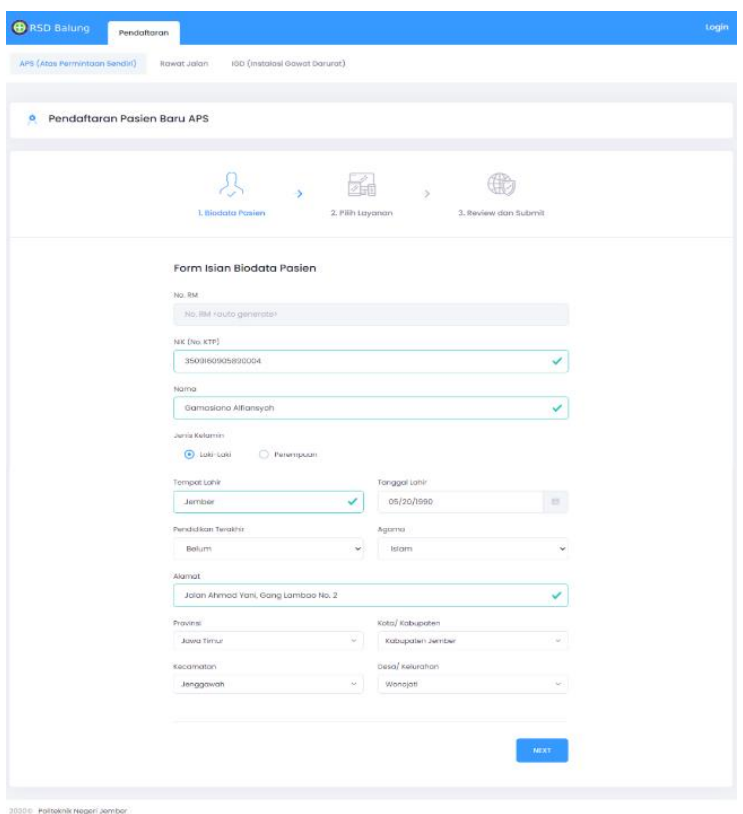

Fig. 4. Form of patient biodata

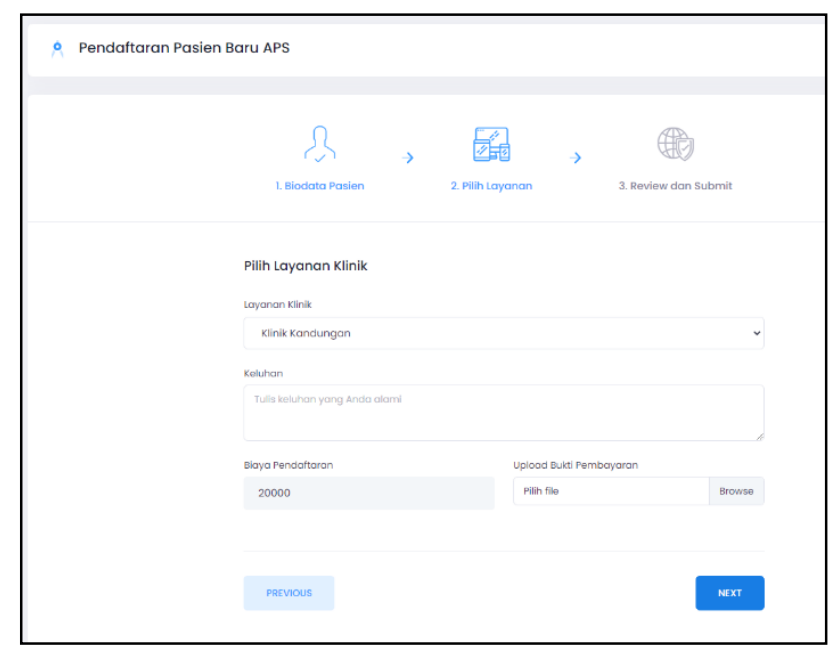

Fig. 5. Form of choosing clinical services

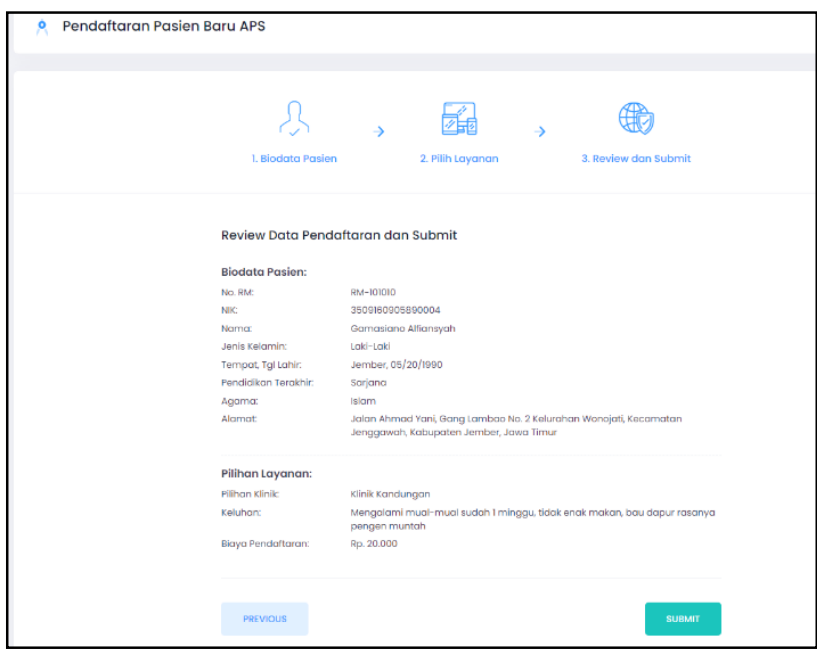

Fig. 6. Reviewing the completed form

This interface was implemented directly in the CodeIgniter4 framework, making it easier for back-end development at a later stage.

\section{CONCLUSION}

Based on the research that has been carried out, it can be concluded that the patient registration system running at Balung Hospital is still manual. System development was carried out by designing a web-based information system that supports the hospital service process, especially important information can be easily accessed widely by users or patients and society at large.

\section{ACKNOWLEDGMENT}

We sincerely thank to Ministry of Education and Culture Republic of Indonesia for the funding support (funds supported by PNPB 2020), Balung Hospital for the data obtained, and Politeknik Negeri Jember for funding the research so that this research can be carried out well.

\section{REFERENCES}

[1] Ministry of Health of the Republic of Indonesia. Law of the Republic of Indonesia Number 44 Year 2009 on Hospitals. Jakarta: State Secretariat of the Republic of Indonesia; 2009

[2] Malhotra, A.K. Hospital management system: An Evaluation. global Indian Publication; 2009 
[3] Ministry of Health of the Republic of Indonesia. Law of the Republic of Indonesia Number 44 Year 2009 on Hospitals. Jakarta: State Secretariat of the Republic of Indonesia; 2009

[4] Sherwin, H. N., McKeown, M., Evans, M. F., \& Bhattacharyya, O. K. The waiting room "wait": From annoyance to opportunity. Canadian Family Physician, 59(5), pp. 479-481; 2013

[5] Reinhold H. Strategic information management in hospitals: an introduction to hospital information systems. New York: Springer Press; 2011

[6] Abdullahi, J.I. Introduction to Computer Management Tool. Nigeria Victory Publishers; 2004
[7] James, E.H, and Cimino, J.J. Biomedical Informatics: Computer Applications in Health Care and Biomedicine, 3rd ed. New York: Springer; 2006

[8] Guoqing H, Ying Y. Integrative management of information resources of enterprises. J China Society Sci Tech Info 2012; 1: 100-7

[9] Bisono, T. Designing a Hospital Outpatient Registration System through a Short Message Service Gateway (Perancangan Sistem Pendaftaran Pasien Rawat Jalan Rumah Sakit Melalui Short Message Service Gateway). Transformatika. Vol. 16, No. 1, pp. 53-66; 2018

[10] Anderson Consulting. The future of European health care. Report for the European Community (HCEC); 1993

[11] Sommerville, Ian. Software Engineering, 6th. Jakarta: Erlangga; 2011 